https://doi.org/10.18485/iipe_response2covid19.2021.ch8

\title{
THE COVID-19 PANDEMIC AND ITS IMPACT ON NATO
}

\begin{abstract}
Ana Jović-Lazić ${ }^{1}$
Abstract: The risks of transmission of contagious diseases are increasing as a result of globalization and the increased movement of goods and people. The fact that these diseases can quickly cross national borders is why the international aspect is becoming more and more important. These risks are complex and disparate from direct military threats but also have a negative effect on security and stability both at the state and global levels. The COVID-19 pandemic has become a big problem and a challenge for individual states, as well as for international and regional organizations. NATO is no different and, like other international organizations, the operational and institutional protocols for the work of its bodies had to be amended to maintain the effective functioning during the COVID-19 crisis. This adjustment modified, but did not significantly impact the main aims and previously defined priorities, despite the fact that the unavoidable global economic downturn could reduce the number of members who can meet the spending targets recommended by NATO. In particular, because the COVID-19 crisis did not reduce international rivalry and insecurity, but rather increased it, with long-term consequences for international security and stability.
\end{abstract}

Keywords: COVID 19, contagious diseases, security, NATO, resilience, international stability.

\section{INTRODUCTION}

When a contagious disease spreads throughout the globe and becomes a pandemic, it poses a non-traditional security threat, since it has the potential to disrupt regular functioning health systems, as well as nations' political and economic

\footnotetext{
${ }^{1}$ Senior Research Fellow, Institute of International Politics and Economics, Belgrade, Serbia. E-mail: anajovic@diplomacy.bg.ac.rs.

The paper presents the findings of a study developed as a part of the research project "Serbia and Challenges in International Relations in 2021", financed by the Ministry of Education, Science, and Technological Development of the Republic of Serbia, and conducted by the Institute of International Politics and Economics, Belgrade.
} 
stability and interests. Recently, humanity was confronted with the COVID-19 virus, which has spread quickly, demonstrating how global connectivity can be both a strength and a vulnerability.

Most countries incorporate non-traditional security threats into their national security strategies and have accordingly engaged all their capabilities in their efforts to respond to the COVID-19 crisis. When the pandemics began, new threats and difficulties required a shift from traditional to non-traditional military operations, as well as the deployment of military personnel to support civilian efforts in various crisis conditions. The important contributions by the military to civilian authorities' attempts to monitor and prevent the spread of the virus during the COVID-19 crisis underscored the importance of a well-functioning civil-military link. The military, which is trained to react quickly in risky situations, was one of the first to react to the pandemic, distributing medical supplies and protective equipment (Lațici, 2020).

Despite all these efforts, national health systems have been shown to be limited in their capacity to protect their citizens and prevent the spread of the virus. Also, although the borders of many countries were quickly closed, which made transportation and trade extremely difficult, this did not prevent the virus from spreading rapidly around the globe. At the same time, fears of the virus have sparked a global scramble for medical protective equipment and respirators. The lack of mutual support and assistance, especially at the beginning of the crisis caused by the COVID-19 virus, marked the relations between many close countries and close allies.

In these circumstances, it has become obvious that an efficient response to pandemics requires the participation and full coordination of all available resources at the state level but also at an international level, especially through cooperation within the framework of regional and international organizations. Thus, a new health crisis has challenged the agendas of key international organizations, as well as their operational and administrative capacities. Monitoring the outbreak of infectious diseases and timely and efficient management of the distribution of medical equipment, protective equipment and respirators have become priority obligations. It has become obvious that it is crucial for international organizations to react quickly and successfully to the crisis, as well as to use it to adjust their missions and tasks. Like many other countries and international organizations, NATO has had to adapt to new global circumstances.

In the first weeks following its outbreak, NATO was repeatedly accused of doing nothing to combat the COVID-19 pandemic. This impression of inaction and discontent persisted in most alliance states, but criticism was also expressed outside of NATO, by Russia and China. However, the Alliance was particularly concerned about criticism coming from the two countries, accusing them of using highly 
effective strategic communication methods to spread untruths about NATO's allegedly inadequate engagement. Furthermore, NATO has accused Russia and China of using assistance for protective equipment, respirators, and medicine as non-traditional foreign policy tools for influencing recipient countries. It has become clear that, despite not being the first line of defence, NATO has to adapt and find a role in the fight against the global health crisis (Rittimann, 2021, pp. 74-80).

Looking at the spread of contagious diseases as a non-traditional security threat, which focuses on human security, this article examines how NATO responded to this health crisis while staying true to its strategic objectives. How has the crisis affected NATO's agenda and, as a result, its planning capacity? To address these issues, the article examines various measures and actions taken by NATO in the organizational and communication domains, as well as the potential impact of the pandemic on the organization's agenda, particularly in terms of military-political planning and response to the broader range of contemporary non-traditional threats.

This article is organized as follows. It begins by presenting the analytical framework by assessing the spreading of contagious diseases as a security threat. Following this approach, the article traces the immediate response of NATO to the pandemic of COVID-19. Then it does a preliminary review of the NATO mandate for dealing with the COVID-19 crisis and the major challenges it faced throughout the outbreak. The article concludes with reflection points on the COVID-19 pandemic and its impact on NATO.

\section{THE SPREADING OF CONTAGIOUS DISEASES AS A SECURITY THREAT}

After the Cold War, security analysts began to focus on more complex threats, not just immediate threats to the country's security, such as military threats. As a result, a wider spectrum of issues might be classified as security threats. Moreover, shifting the focus from threat to risk has allowed security to move away from the concept of a clear danger to more plausible assessments of potential threats. As a result, risks to public health may be viewed as a type of non-traditional security threat. At the same time, questions are raised not only about the challenges posed by security threats, but also about whose security should be protected. Because these threats are not directly related to the protection of the state's sovereignty, but rather affect individuals within states, the concept of human security was developed. ${ }^{2}$ This concept can also be applied to explain the need for an adequate

2 The phrase "global health security" was created by the World Health Organization (Mclnnes, 2008, pp. 276-277). 
response to the security challenges posed by the spread of contagious diseases (Sergeev \& Lee, 2020, p. 57). Because it jeopardizes people's health and well-being, a pandemic may cause chaos in a country's health, economic, and social systems, generating widespread panic and undermining the country's stability and functioning (Mclnnes, 2008, p. 279).

Contagious diseases have always spread across national borders. In recent decades, climate change, rapid population growth, significant depletion of natural habitats, high levels of urbanization that bring people closer to wild species and shifting disease transmission patterns between human and animal populations all contribute to the emergence of different contagious diseases. At the same time, predicting and responding to epidemics, as well as preventing them from becoming pandemics, is extremely difficult, given the wide range of their potential origins and the fact that, due to globalization, contagious diseases may spread quickly (Bloom \& Cadarette, 2019). Growing global interconnectivity also creates mutual vulnerability, complicating an already difficult task that requires both a global and a national approach. (Cecchine \& Moore, 2006, p. 6).

International organizations have an important function because they represent organized platforms for consulting countries on global issues and agreeing on measures to be implemented at the national level. In the securitization of contagious diseases, the World Health Organization (WHO) has played a critical role. ${ }^{3}$ As a result, the WHO has presented the spread of contagious diseases as an existential threat that requires new regulations and behaviour of the international community in order to effectively control them. This organization released a list of contagious diseases for research and development aims in May 2016, which was later revised several times. (Davies, 2008, pp. 295-313). This WHO document also emphasized that contagious disease outbreaks pose a substantial and ongoing danger to global health, economic prospects, as well as to security. The UN has also recognized that contagious diseases can become security threats. A few UN Security Council Special Sessions and resolutions have been dedicated to AIDS, the global reaction to SARS, H5N1, and now COVID-19. They resulted in the initiation of a number of wellcoordinated campaigns that were carried out with tactical accuracy and commitment and backed up by military rhetoric. The terminology used to emphasize the need to

\footnotetext{
${ }^{3}$ The concept of securitization was brought to the study of international affairs by the Copenhagen School. Buzan describes security as a self-referential activity since it is via this practice that the issue becomes a security risk, not necessarily because a real existential threat exists, but because the issue is presented as such (Buzan B. \& Waever O. \& de Wilde J., 1998, p. 25).
} 
remove certain infections was combative, with references to an "enemy" to be defeated and battles to be won (O'Manique \& Fourie, 2010, p. 243).

The crisis caused by COVID-19 has required continuous monitoring and the ability to react and adapt quickly. The outbreak of the COVID-19 virus disease was declared a Public Health Emergency of International Concern by the WHO on January 30, 2020. The WHO Director-General proclaimed a pandemic on March 11, 2020. Thus, the World Health Organization securitized the spread of the COVID-19 virus, prompting a rapid worldwide reaction through a variety of national and global measures. Its Strategic Preparedness and Response Plan, which was released on February 4, 2020, was aimed at incorporating all possible national and global resources in an effort to respond to the virus's spread and allow its containment and suppression (WHO, February 2020).

The WHO seeks to fulfil its mandate by securitizing communicable diseases at a global level, but national governments are obligated to work to protect the health of their own citizens. Although the state policies of most countries have largely followed the recommendations of the WTO, the crisis caused by the spread of the COVID-19 virus, as Trapara noticed, has restored the importance of decisions at the national level (Trapara, 2021, p.48). Namely, since the beginning of the pandemic, national governments have sovereignly decided on strategies and measures to implement the fight against this virus, often significantly restricting civil and political rights and freedoms. In many countries, they have achieved this with the broad support of the population (Dodds et al., 2020, pp.292-293). On the other hand, as Fiddler pointed out, international cooperation and coordination in the control of contagious diseases are crucial when it becomes a global issue because no state can independently prevent the spread of deadly viruses within its borders (David, 1997). It is crucial to emphasize that, despite interdependence and the necessity for international collaboration and information exchange, outbreaks of the COVID19 crisis have shown that policies within and amongst states can lead to an atmosphere that disrupts the steps required to protect states and individuals from communicable diseases.

There have been numerous examples of government activities at all levels of the international community that have had a negative impact on coordination activities against the spreading of the COVID-19 pandemic, and which harmed international law. The most obvious thing was the open rivalry and competition between the United States, China, and Russia, which did not stop during the pandemic. ${ }^{4}$ Furthermore, the pandemic heightened mutual hostility (Fidler, 2020).

\footnotetext{
${ }^{4}$ Otherwise, for a long time, the relations between NATO and Russia did not coincide with
} the true interests of strengthening European security on a collective basis (Jović-Lazić, 
As Biscop noticed, the pandemic has become another arena in which a great power competition has been played out. Some governments used speculation and false narratives against each other, attempting to influence the $\mathrm{WHO}$ and persuade the public to believe in their version of events (Biscop, 2020, pp. 1009-1023). As a result, the $\mathrm{WHO}$, as a multilateral organization, has become a focal point for the growing competition between the US and China. This mutual animosity, in many forms, has hampered collaboration and the accomplishment of an effective global response to COVID-19. As Lefler noted, the pandemic drew attention to the rise of China and the rivalry of the great powers. But he believes that transnational threats, which are related to climate change and global warming, represent the greatest long-term global threat, rather than great power competition (Leffler, 2021, pp. 517-524).

\section{THE IMMEDIATE RESPONSE OF NATO TO THE COVID-19 PANDEMIC}

To fully comprehend NATO's actions and limitations during the COVID-19 crisis, one must first comprehend the overall framework in which the alliance was functioning during the period before its outbreak. Because the patterns of the further development of the pandemic are not obvious, and there is no clear opponent or state that can be identified and fought against, the crisis caused by the spread of the COVID-19 virus is different from the crises that NATO has faced before. Nobody genuinely believed that fighting a pandemic was NATO's responsibility. In their defence policies, most NATO member nations recognize that the fundamental responsibility of the state is to preserve state security, but they also recognize human security, which implies that citizens and individuals must be protected and safe (Tardy, 2020, p. 16).

At the start of the crisis, relations between the allies were marked by the lack of mutual support and help, as well as the absolute supremacy of sovereign governments, both in terms of legitimacy and resources available to tackle this security danger. Although several EU member states closed their borders during the first phases of the pandemic, the decision of the US president to impose a travel restriction against Europe on March 11, 2020, was interpreted as an unwillingness of the United States to take a leading role in the transatlantic response to spreading

2015, pp. 151-172). In addition to numerous common interests, there are also significant differences and contradictions, both in international positions and in the immediate and long-term goals of the US, the EU, and Russia. An effective fight against a number of new threats and challenges in the world will, ultimately, require the restructuring of EU-NATO relations, as well as the development of a more concrete strategy for cooperation between the USA, the EU and Russia (pp. 303-325; Jović-Lazić \& Lađevac, 2021, pp. 215-235). 
the virus. As a result of all of this, questions concerning the future of liberal internationalism, transatlantic relations, and NATO's role as a military alliance have become pretty widespread (Brattberg, 2020).

In an attempt to respond to the new situation, NATO has acknowledged its responsibility for preventing the health crisis from escalating into a dangerous security crisis. NATO insisted that the nature of the COVID-19 crisis required a coordinated response and action at the local and international levels. In this context, its role as an international security organization is to contribute to a more effective response by its member states to this health crisis (NATO, June 2020). In its public pandemic discourse, NATO has emphasized its experience of crisis management and crisis-specific tasks, such as strategic airlift, which proved beneficial during the COVID-19 outbreak (Baciu, 2021, p. 4).

Given the high virulence of COVID-19, as well as the fact that there were no adequate medicines or vaccines at the beginning of the pandemic, the fight against the pandemic was aimed at early diagnosis and prevention of spread (Fidler, 2020). NATO has also focused on preventing the spread of the virus and mobilizing its resources to help allied countries and partners supply medical protective equipment and respirators. At the same time, it has taken the necessary steps to adjust its management and decision-making processes, not only at the diplomatic and political levels but also at the military and operational levels (Lațici, 2020).

Because NATO troops are also vulnerable to COVID-19, the introduction of quarantine, as well as a rise in the number of infected military personnel, has had an impact on NATO force planning, deployment, and operations. Thus, in order to prevent the disease from spreading within its forces, the US Military Command in Europe (EUCOM) declared on March 13, 2020, that it had reduced the size and scope of exercise Defender-Europe 20, and that all staff and equipment movement from the US to Europe had stopped. Otherwise, the purpose of these exercises was to see how quickly the US could get 20,000 troops to Europe and position them near the Russian border. Also, it was announced that while the necessary changes were being carried out, the exercises related to the Defender-Europe 20 exercise Dynamic Front, Joint War Assessment, Saber Strike, and Swift Response - would be cancelled (NATO, March 2020).

NATO has adapted as the crisis caused by the spread of the COVID-19 virus progresses. On the 2nd of April 2020, NATO member states' foreign ministers met digitally for the first time in the Alliance's history. To prevent the COVID-19 virus from spreading further, NATO Headquarters implemented preventive measures such as restricting access to the media and non-essential personnel. These regulations obeyed the Belgian government's movement restrictions, which had been in place since March 18th. This was an opportunity to talk about how to react rapidly and 
efficiently to the global health crisis, as well as how to preserve stability during a pandemic while stressing that the economic implications of a pandemic could put the Alliance's budget in jeopardy. The brief final declaration of the Council on April 2, 2020, stresses the argument that NATO, in the face of an unprecedented pandemic, is fulfilling its role. In that sense, it is emphasized that allies help one another in a variety of areas, such as emergency personnel, medical supply delivery to hospitals, and best practices for treating this disease (NATO, April 2020). Other virtual meetings followed this meeting of foreign ministers. There are opinions that this approach was useful in dealing with pandemic outbreak problems, but because it allows NATO to make rapid decisions, it may be essential in other crisis circumstances and increases the Alliance's deterrence (Chollet et al. 2020, pp. 2-3).

The possibility of overcrowded and under-resourced hospitals among the Allies severely afflicted by the virus was initially a cause of anxiety. The Allies were compelled to analyze their available stockpiles of a variety of critical protective and medical equipment immediately. As the COVID-19 virus spread around the globe, it was clear that the demand for supplies and equipment was changing. Therefore, the Allies worked together to develop a strategy to ensure that it was delivered as quickly as possible to the locations where it was necessary. NATO's experience of crisis management and coordinating logistics among Allies has allowed it to contribute effectively to its members' responses to the COVID-19 crisis. To secure the capacity to transfer the appropriate quantity of supplies and personnel on time, NATO has engaged in a variety of essential instruments to address more effective logistics and supply chain coordination, strategic airlift, and fast air mobility. They were also crucial for leading and managing NATO's total military operation in support of Allied and partnership activities throughout the crisis (Mesterhazy, 2020).

The Euro-Atlantic Disaster Response Coordination Center (EADRCC), which was established in June 1998, was developed as NATO's primary response tool for responding to civil crises in the Euro-Atlantic region. Its goal is to make civil and military assistance more accessible during natural and man-made crises, emergencies, and Article 5. It serves as a centre for coordinating relief requests and providing assistance to NATO Allies and Partners. Thus, during the pandemic, the EADRCC has assisted in the coordination of donations to many NATO member countries and partners that have requested them (NATO, EADRCC). The necessity for organized and efficient assistance is significant when the resources are provided at a critical time when they can save lives. While doing so, it is very important to avoid duplication of capacities. In this regard, the EADRCC's role in organizing assistance across the Euro-Atlantic region during the COVID-19 crisis has been essential. Besides the EADRCC, the NATO Support and Procurement Agency (NSPA) also has decades of expertise in responding to crises, which was crucial in 
responding to the crisis caused by the COVID-19 pandemic. The NSPA, established in 1958, integrates procurement, logistical, medical, and infrastructure capabilities, operational and systems support, and services for NATO states, NATO Military Authorities, and partner nations into a single body (NATO, NSPA). As a result, during the pandemic outbreak, the NSPA has provided significant airlift capacities as well as assistance in the acquisition and delivery of critical medical equipment and supplies. The NSPA created the COVID-19 Management Office (CMO) at the onset of the crisis to address the nation's unprecedented demand for medical supplies, equipment, and services (NSPA, COVID-19). Also, the Strategic Airlift Capability (SAC), the Strategic Airlift International Solution (SALIS), and the Rapid Air Mobility (RAM) have all been launched by the Alliance to help with transportation efficiency for the delivery of vital medical protective equipment to combat the coronavirus pandemic (NATO, RAM). Hundreds of transport missions for medical supplies, equipment or personnel took place during the COVID-19 crisis. Thus, the pandemic has resulted in the largest military deployment in history during a period of peace. About half a million soldiers have been deployed to support the civilian response to the pandemic since it began. For military relief flights, the NATO call sign has been used to ensure a swift response (Lațici, 2020b).

According to the Special Report of the Defense and Security Committee of the NATO Parliamentary Assembly from November 2020, NATO's pandemic crisis response policy does not jeopardize its ability to provide credible and effective deterrence and that its forces remain on alert in case of an attack. Also, as further stated, missions and operations critical to the Alliance's security are fully staffed and focused on fulfilling their goals (Mesterhazy, 2020). For the Alliance, it was critical to demonstrate to the international community and its allies that NATO used its capabilities and resources to directly participate in the fight against COVID-19 while also remaining ready to fulfil its primary missions of collective defence, crisis management, and cooperative security (NATO, April 2020).

\section{THE NATO MANDATE FOR DEALING WITH THE COVID-19 CRISIS AND THE MAJOR CHALLENGES IT FACED THROUGHOUT THE OUTBREAK}

Dealing with the effects of pandemics is primarily the responsibility of national governments, but given that the COVID-19 crisis had significant security implications for its member states, this prompted NATO to adapt. Crisis management has been critical in responding to the COVID-19 pandemic crisis. As a result, NATO decided to serve as a crisis manager. The importance that NATO countries give to crisis management is reflected in the Strategic concept published in 1999, which sets crisis management as one of the basic security responsibilities of the Alliance. This 
concept defines the key security goals and tasks for which effective processes have been established to guide participants in crisis planning, preparedness, and management (NATO, 1999). It was then estimated that this unique instrument for multinational military cooperation could contribute to crisis management by integrating the efforts of its member states and other partners. However, as Roper noted back then, in order to prevent misunderstandings and false expectations, NATO should carefully define its capabilities and accept that it will be as successful as its member states allow (Roper, 1999, pp. 51-61).

Crisis management was also identified as a crucial task in NATO's 2010 Strategic Concept Strategy. According to this Strategy, NATO is dedicated to collective defence, crisis management, and cooperative security in order to defend its members. This document states that "NATO has a unique and robust set of political and military capabilities to address the full spectrum of crises... NATO will actively employ an appropriate mix of those political and military tools to help manage developing crises that have the potential to affect Alliance security". It is further stated that the contemporary security environment comprises different threats to the security of the territory and populations of its member states. Health risks are, among others, recognized as a non-traditional threat with the potential to significantly influence NATO strategy and operations (NATO, 2010). Civil crisis planning is particularly critical because it allows allies and partners to help each other improve individual governments' civilian ability to deal with diverse threats and, as a result, prepare to deal with the consequences of potential crises.

NATO has tried to preserve its operational capacities and its ability to deal with a wide range of security issues, even in times of crisis. During the COVID-19 crisis, NATO adapted by taking on additional crisis-related emergency tasks such as the transfer of medical equipment, resource coordination, and mobility. NATO highlighted the significance of its instruments and capabilities, focusing on risk analysis, healthcare and medical equipment transport, fighting hybrid threats, and the protection of critical infrastructure sectors. (NATO, 2021).

NATO's mandate to strengthen resilience became essential to the official Alliance discourse and was often underlined in its response to the COVID-19 crisis. The principle is codified in Article 3 of the Alliance's founding treaty, which states that the parties, individually and together, shall preserve and strengthen their individual and collective resilience capabilities via constant and effective self-help and mutual assistance. In the NATO Secretary General's Annual Report 2020, resilience is recognized as the "first line of allied deterrence and defence" (NATO, 2021).

The COVID-19 crisis has further forced NATO to assess, adapt, and implement plans for large-scale emergency or crisis scenarios, particularly those involving public health. Planning in a civil crisis is particularly important because it allows allies and 
partners to help each other improve individual governments' civilian ability to deal with diverse threats and, as a result, prepare to deal with the consequences of potential crises. The NATO Civil Emergency Planning Committee (CEPC), which was established decades ago, could play a significant role in dealing with similar crises. It is one of the key tools in the field of civil protection, but also in repairing the consequences of natural and other emergencies (Heuven \& Marten, 1970, pp. 391398).

In an effort to generate recommendations in order to create a basis for the revision of its Strategic Concept, in November 2020, NATO adopted the document "NATO 2030: United for a New Era". An evaluation of what the COVID-19 pandemic has revealed about NATO's capacity to deal with multiple, simultaneous, disruptive, and non-traditional threats, as well as meeting basic resilience requirements such as minimizing damage, quickly restoring stability, and catalyzing improved strategies for future challenges, are recognized as essential. As further stated in this document, NATO could continue to undertake lessons-learned exercises from the COVID-19 crisis with a strategy to meet unforeseen challenges in the context of strategic simultaneity. It also highlighted that NATO's capacity to maintain security and defence requirements in the face of various disruptions should be examined. It also points out that non-military threats such as the outbreaks of contagious diseases can be recognized in NATO's resilience and crisis management planning. Also, NATO should adopt a regular training plan to provide allies with the ability to predict and simulate strategic shocks caused by natural and man-made disasters. The aim, it concludes, should be to ensure that assigned duties and relevant information exist before any possible crisis (NATO, November 2020).

Governments and international organizations have geostrategic or regional interests in conveying certain messages to areas and countries where they have or want to exert influence. Thus, it is not surprising that the COVID-19 crisis provided another opportunity to demonstrate the obvious geopolitical interests of major international actors. In that context, a pandemic has also increased international rivalry and uncertainty, with long-term implications for international stability.

NATO does not approve of Russia's and China's foreign policies, which is why they have been attempting to discredit these countries in numerous ways since the outbreak, accusing them of using the pandemic for commercial and political gain. Thus, NATO claimed that it had noticed a lot of confusion and misinformation and that it had therefore begun to regularly monitor the disinformation and propaganda operations of many state and non-state actors. NATO also accused Russia and China of working together to change the narrative surrounding the COVID-19 pandemic. In its official documents, NATO stated that Russia was attempting to smear the Alliance's ability to respond to crises, as well as that China wanted to change the 
discourse from being the source of a worldwide pandemic to being a state capable of fulfilling the growing demands in moments of a global health crisis. It is also noted that both Russia and China are actively disseminating deliberate disinformation through diversified and numerous media forms and that NATO is taking the required steps to address Russia's destructive and disinformation tactics, as well as China's subtle attempt to change the virus's origin story (Mesterhazy, 2020). Regardless of these NATO accusations, it needs to be noted that there is a belief that, under current conditions, maintaining the Alliance's traditional political goals will be increasingly harder to explain because ordinary people are unaware of Russia's and China's heightened aggressiveness, which NATO views as security challenges. Especially since, as Russel pointed out, China, unlike many Western countries, was able to respond quickly and effectively, which is advantageous in times of crisis (Mead, 2020). Contrary to this, the United States, as the dominant power at the global level, was not ready and did not have the capacity to take a leading role in this crisis (Gullestad et al., 2020, pp. 3-4). But, as Nye observed, although its reputational (or soft) power has suffered as a result of its incompetent response, the pandemic will not change the balance of hard power in favour of the United States. COVID-19, according to Ikenberry, will hasten the fragmentation and disintegration of the global order in the short term. But, as he points out, the pandemic also provides an opportunity to recover the liberal international mission. He claims that this is the final chance to create an open, global system based on a coalition of major liberal democracies (Ikenberry, 2020). Also, despite speculation that the long-term economic effect of the pandemic could jeopardize NATO's future budget, posing an existential threat to the Alliance, no such outcome is expected. In the official narrative, the justification for national allocations to the Alliance's budget is already based on the existence of non-traditional security threats, such as health threats, and the need to be more prepared to respond to similar challenges in the future (NATO, November 2020).

\section{CONCLUDING REMARKS}

Due to globalization and increased urbanization, an increasing number of new contagious diseases can be transmitted more rapidly to different geographical regions, increasing the risk of a pandemic with global consequences. Although each state is responsible for dealing with health crises that occur within its borders, as we have seen during the COVID-19 pandemics, the repercussions, escalation of harmful implications, or duration that deplete state resources frequently exceed the capacity of individual states, which are unable to deal with the consequences of the negative phenomena that strike them. The COVID-19 pandemic has shown that the spread of the virus can have a negative impact not only on public health 
but also on social, economic, and political structures, becoming a real threat to both national and global security. In such cases, international cooperation is essential.

Despite the fact that the pandemic was supposed to be the initiator of international cooperation, in the first reaction to the outbreak of COVID-19, solidarity even between very close states and allies for the supply of critical medical devices and protective equipment did not exist. Although NATO has faced operational, budgetary, and political challenges that have prevented it from having a significant impact on member governments, the COVID-19 crisis has forced the Alliance to adjust to such threats in a credible way. NATO has reduced the scope of its activities, postponed or cancelled some previously agreed-upon exercises, and deactivated some contingents. The virus also affected a segment of the NATO force. Nevertheless, NATO has shown its ability to adapt to the new situation and mobilize its capabilities to directly support the member states' response to the crisis posed by the COVID-19 pandemic. Thus, this organization has activated some of its existing complex instruments developed before the COVID-19 crisis to support the civilian action of its allies.

In its official rhetoric, NATO sought to show its importance by arguing that it wanted to prevent this, above all, health crisis from escalating into a serious security crisis. In this context, NATO recognized the need for civil-military cooperation, as well as the opportunity provided by the deployment of military capabilities to address the challenges of the COVID-19 crisis. NATO's main priority in such a complex situation was to maintain its defensive position of readiness and credibility.

During the COVID-19 crisis, NATO also identified new challenges, which is why the Allies reconstructed the organization's agenda to make it more resilient to future pandemics. However, official NATO documents concluded that the principle of resistance should be applied, not only to the spread of infectious diseases but also to a wider range of non-traditional threats. NATO identified official and unofficial actions and practices of other important global actors during the COVID-19 pandemic, especially Russia and China, as a threat to its security. More specifically, the Alliance wanted to prevent the spread of misinformation about its ability to contribute to the member states' response to the COVID-19 crisis, which could undermine its internal unity and ability to fulfil its mandate. Especially since the pandemic has highlighted issues that have existed in the transatlantic community for some time. First of all, the lack of American leadership and mutual trust was noticeable, which further weakened transatlantic ties during the COVID-19 crisis. Also, the fact that the pandemic has a direct economic impact, there are fears that the defence sector will not be immune to the long-term consequences of the global recession.

So, although the coronavirus pandemic posed a unique security challenge, at the same time, this type of crisis does not alleviate international tensions. As a result, 
some security threats to NATO have worsened, while new ones have emerged. Thus, the COVID-19 pandemic did not significantly jeopardize the Alliance's existing operations, missions or responsibilities, but presented a request to adapt to new circumstances, which include not only traditional security challenges, but also nontraditional challenges directly related to human security.

\section{REFERENCES}

Baciu, C. (2021). Beyond the Emergency Problematique. How Do Security IOs Respond to Crises-A Case Study of NATO response to COVID-19, Journal of Transatlantic Studies, Vol. 19(3).

Biscop, S. (2020). No peace from corona: defining EU strategy for the 2020s, Journal of European Integration, Vol. 42(8), pp. 1009-1023.

Bloom, D. E. \& Cadarette, D. (2019). Infectious Disease Threats in the Twenty-First Century: Strengthening the Global Response, Front Immunol, 10: 549, doi: 10.3389/fimmu.2019.00549.

Brattberg, E. (2020). The troubling impact of covid-19 on transatlantic relations, retrieved from http://confrontations.org/wp-content/uploads/2020/ 05/Confrontations-Revue-128-EN Transatlantic.pdf. Assessed 23 May 2021.

Buzan, B. \& Waever, O. \& de Wilde J. (1998) Security: a new framework for analysis, London.

Cecchine, G. \& Moore, M. (2006) Challenges of and Responses to Infectious Disease Threats, in: Infectious Disease and National Security, RAND Corporation\&JSTOR.

Chollet, D. et al. (2020). How is the Coronavirus Pandemic Changing Thinking on Security?,Transatlantic Take, The German Marshall Fund, Washington.

Davies S. E. (2008). Securitizing Infectious Disease, International Affairs, Vol. 84(2), pp. 295-313.

Dodds, K. et al. (2020). The COVID-19 pandemic: territorial, political and governance dimensions of the crisis, Territory, Politics, Governance, Vol. 8(3), pp. 289-298.

Fidler, D. (1997). The Globalization of Public Health: Emerging Infectious Diseases and International Relations, Indiana Journal of Global Legal Studies: Vol. 5(1), pp. 11-51.

Fidler, D. (2020). To Fight a New Coronavirus: The COVID-19 Pandemic, Political Herd Immunity, and Global Health Jurisprudence, Chinese Journal of International Law. doi: 10.1093/chinesejil/jmaa016.

Gullestad R. J. \& Bjur I. \& Eggen K.A. \& Allers R (2020). Introduction (pp. 3-4), in: Gullestad et al. (Eds.). The Global Pandemic. Transatlantic Security and National 
Defence: Views from the United States, the United Kingdom, Germany and Norway. 2020. IFS Insights 6/2020.

Heuven, V. \& Marten, H. A. (1970). Civil Emergency Planning in NATO, The International Lawyer, Vol. 4(2), pp. 391-398.

Ikenberry J. (2020). The Next Liberal Order, The Age of Contagion Demands More Internationalism, Foreign Affairs, Vol. 99(4).

Jović-Lazić, A. (2015). Odnosi između Evropske unije i Ruske Federacije: kraj XX i početak XXI veka [Relations between the European Union and the Russian Federation: the end of the XX and the beginning of the XXI century], 2015.

Jović-Lazić, A.\& Lađevac, I. (2021). Redefining Russia-European Union Relations Is It Possible to Overcome a Deep Crisis? (pp. 215-235), in:Europe in Changes: the Old Continent at New Crossroads, Katarina Zakić and Birgül Demirtaş (Eds.),IIPE.

Lațici T. (2020b) NATO's response in the fight against coronavirus, retrieved from https://www.europarl.europa.eu/RegData/etudes/ATAG/2020/651955/EPRS_A TA(2020)651955_EN.pdf. Assessed 11 April 2021.

Lațici T. (2020a). The role of armed forces in the fight against coronavirus, retrieved from https://www.europarl.europa.eu/RegData/etudes/BRIE/2020/649401/ EPRS_BRI(2020)649401_EN.pdf. Assessed 19 March 2021.

Leffler, M. P. (2021). Ruminating during a Pandemic, Diplomatic History, Vol. 45(3), pp. 517-524.

Mclnnes, C. (2008), Health, in: Security Studies(pp. 276-277). Paul D. Williams (Ed.), Routledge.

Mead, W. R. (2020). The Pandemic: A Global Review, retrieved from https://www. hudson.org/research/16128-the-pandemic-a-global-review. Assessed 2 May 2021.

Mesterhazy, A. (2020). NATO's essential role in the COVID-19 pandemic, retrieved from https:// www.nato-pa.int/document/2020-natos-essential-role-covid-19pandemic-revised-draft-report-mesterhazy-091-dsc-20-e. Assessed 30 May 2021.

Nye, J. (2020) No, the Coronavirus Will not Change the Global Order, retrieved from https://foreignpolicy.com/2020/04/16/coronavirus-pandemic-china-unitedstates-power-competition/. Assessed 21 May 2021.

O'Manique, C. \& Fourie, P. (2010). Security and health in the twenty-first century (pp. 243-253),in: M. D. Cavelty, \& V. Mauer (Eds.), The Routledge handbook of security studies. 
Rittimann, O. (2021). Die NATO und die COVID-19 Pandemie, SIRIUS - Zeitschrift für Strategische Analysen, Vol. 5(1), pp. 74-80.

Roper, J. (1999). NATO's New Role in Crisis Management, The International Spectator, Vol. 34(2), pp. 51-61.

Sergeev, A. \& Lee, J. (2020). From State Security to Human Security: The Evolving Nature of the United Nations Security Council's Jurisdiction, Inter Gentes, Vol. 2(2), pp. 44-63.

Tardy, T. (2020). COVID-19: shaping future threats and security policies(pp. 13-20), in:Thierry Tardy (Ed.), COVID-19: NATO in the Age of Pandemics,No. 9.

Trapara, V. (2021), Međunarodni odnosi u doba korone: preispitivanje koncepta entropije [International relations in the age of the corona: a re-examination of the concept of entropy], Međunarodni problemi, Vol. LXXIII(1), pp. 39-57.

NATO. (1999). The Alliance's Strategic Concept, retrieved from https://www.nato.int/ cps/en/natolive/official_texts_27433.htm. Assessed 28 March 2021.

NATO. (2010). Strategic Concept for the Defence and Security of the Members of the North Atlantic Treaty Organization, retrieved from https://www.nato.int/ nato_static_fl2014/assets/pdf/pdf_publications/20120214_strategic-concept2010-eng.pdf. Assessed 8 May 2021.

NATO. (2021). The Secretary General's Annual Report 2020, retrieved from https://www.nato.int/nato_static_fl2014/assets/pdf/2021/3/pdf/sgar20-en.pdf. Assessed 29 March 2021.

NATO. (April 2020). Declaration by NATO Foreign Ministers, 2nd April 2020, retrieved from https://www.nato.int/cps/ru/natohq/official_texts_174855.htm?selected Locale=en. Assessed 22 April 2021.

NATO. (June 2020). The Geopolitical Implications of COVID-19. Speech by NATO Secretary General Jens Stoltenberg, retrieved from https://www.nato.int/ cps/en/natohq/opinions_176983. htm.Assessed 18 April 2021.

NATO. (March 2020). Exercise Defender-Europe 20 Announcement - COVID-19 Implications, retrieved from https://shape.nato.int/defender-europe/defender/ newsroom/exercise-defendereurope-20-announcement-covid19-implications. Assessed 17 April 2021.

NATO. (November 2020). Pandemics and Natural Disasters. In NATO 2030: United for a New Era, retrieved from https://www.nato.int/nato_static_fl2014/assets/ pdf/2020/12/pdf/201201-Reflection-Group-Final-Report-Uni.pdf. Assessed 14 May 2021. 
NATO. Euro-Atlantic Disaster Response Coordination Centre (EADRCC), retrieved from https://www.nato.int/cps/en/natohq/topics_117757.htm. Assessed 12 May 2021.

NATO. NATO Support and Procurement Agency (NSPA), retrieved from https://www.nspa.nato.int/about/nspa. Assessed 17 April 2021.

NATO. NSPA Response to the COVID-19 pandemic, retrieved from https://www. nspa.nato.int/covid19. Assessed 18 April 2021.

NATO. Rapid Air Mobility (RAM), retrieved from https://www.nato.int/cps/ en/natohq/topics_175432.htm. Assessed 18 April 2021.

WHO (2020, February). 2019 Novel Coronavirus (2019-nCoV): Strategic preparedness and response plan, retrieved from https://www.who.int/ publications/i/item/strategic-preparedness-and-response-plan-for-the-newcoronavirus. Assessed 30 May 2021. 